\title{
The Controversial Skill of Columbus as a Navigator: An Enduring Historical Enigma
}

\author{
Douglas T. Peck \\ (Independent Historian) \\ (Email: peckhistory@earthlink.net)
}

\begin{abstract}
This study of Columbus' navigation is unique because it was written by an historian who is also a trained and experienced professional global (and ocean) navigator, rather than an academic historian with only superficial knowledge of the science of navigation as practiced by Columbus and other early navigators. The study is also unique in that as an American historian author disagrees with his colleagues in the USA who present the "politically correct" view of Columbus as an unskilled entrepreneur who obtained his limited knowledge of navigation as a crew member or passenger on Portuguese voyages, rather than as one of the most skilled and experienced of the cadre of respected Genoese captains and navigators used by kings throughout Europe to perform their maritime enterprises.
\end{abstract}

\section{KEY WORDS}

$\begin{array}{lll}\text { 1. Columbus. } & \text { 2. Navigation history. }\end{array}$

1. INTRODUCTION. Current biographers and historians differ widely over Columbus' expertise and experience in seafaring and navigation. And there are significant differences and opposing views related to the skill of Columbus as a captain and pilot (navigator) between the published works from Europe and those of the USA. In Europe the works of De Lollis (1892), ${ }^{1}$ Jane $(1988),{ }^{2}$ Taviani $(1933,1985),{ }^{3}$ and Varela $(1985)^{4}$ picture Columbus as one of the most skilled and experienced of the cadre of Genoese captains and pilots sought by kings and leading ship-owner merchants throughout Europe to conduct their maritime endeavors. But in the USA the works of Davidson (1997), ${ }^{5}$ Morison (1942, 1974), ${ }^{6}$ Henige (1991), ${ }^{7}$ and Wilford $(1991)^{8}$ picture Columbus as a relatively unschooled entrepreneur whose limited experience at sea prior to 1492 was derived primarily as a minor crew member or passenger on Portuguese voyages. A resolution of which one of these opposing views is historically well-founded and more accurate is provided by this study.

2. GENOESE TRAINING. There is a considerable school of thought that pictures Columbus as largely unschooled in his early years, but this does not stand the test of documented and reliable evidence. Morison voiced the unfounded consensus of many biographers and historians when he stated that in Columbus' 
voyages as an apprentice seaman he learned only minor skills and: "As yet illiterate, he could not navigate and thus rate an officer's billet" (Morison 1974, 13). With his father entrenched in the organized and respected weaving trade Columbus would have attended the weaver's guild school as a child. The early guild schools in Italy gave a basic education that was far ahead of the schools in Spain, Portugal and northern and western Europe. In Italian coastal port cities this quality education in guild schools would have included basic mathematics and skills related to seafaring and navigation. The Genoese annalists Bartolomé Senaraga and Antonio Gallo wrote of Christopher and Bartolomé Columbus that "having reached puberty, according to the custom of the people, they had begun to navigate" (Taviani 1985, 44). Also Ferdinand in the biography of his father stated; "he learned his letters at a tender age" (Keen 1992, 6), ${ }^{9}$ and Las Casas confirmed that his parents insisted he not only learned to read and write, but this early education extended with the same degree of excellence to mathematics and cartography (Las Casas 1951, 52-54). ${ }^{10}$ This insistence on obtaining a skill in cartography extended to Columbus' younger brother Bartolomé who later became a recognized captain, pilot, and cartographer in the large influential Genoese colony in Lisbon (Taviani 1985:354-355,376).

In the thirteenth, fourteenth, and fifteenth centuries, Genoese trained seamen were recognized in Portugal and throughout Europe (i.e. Cabot in England, Verrazano in France, and Columbus in Portugal and Spain) for their superiority in seamanship and navigation; a documented historical fact that prominent Columbian scholars either overlook or refuse to accept. The historical truth of Genoese superiority in seamanship and navigation in the fourteenth-century was revealed when the Portuguese monarch King Denis realized his seafaring subjects were unskilled in offshore seamanship and navigation and so turned to the Genoese for help. In 1317, King Denis commissioned the experienced Genoese captain, Manuele Passagno, as Grand Admiral of the Navy for life to ensure that the Portuguese navy and merchant fleet had skilled Genoese sea captains (such as Columbus) to instruct the Portuguese pilots and lead the fleet when required (Taviani 1985:354). This action spawned a large Genoese colony in Lisbon (Peck 2007:(1), 473-474) ${ }^{11}$ composed of skilled Genoese captains, pilots, and cartographers. Cartographers of this influential Genoese colony (of which Bartolomé Colón was a respected member) were responsible for maintaining the Portuguese World Map or Padrao and produced the well-known "Caveri" and "Cantino" World Maps, made even more famous by Waldseemuller's plagiarized copies. This Genoese colony was also the operating base for wealthy Genoese merchant ship owners such as the Spinola brothers and Paolo Di Negro, who used Columbus as captain of one of their ships on many occasions during his stay in Portugal (Taviani 1985, 47).

3. PORTUGUESE NAVIGATION. The general consensus that the Portuguese were leaders in navigation and Columbus learned his navigation while in Portugal, rather than from his early Genoese training, was initially promoted by prominent (but manifestly biased) Portuguese historians, Bensuade, Coutinho, Fontoura da Costa, and Cortesao (Taviani 1985, 302). Early Spanish historians can also be accused of this nationalistic bias (Martyr and Bernaldez are the most prominent), but Taviani noted that even the Portuguese historian Joao de Barros declared that "the Italians [Genoese] were the true first masters of the Portuguese in 
the nautical art; for the latter's [Portuguese's] nautical knowledge, even in the fifteenth-century, did not allow them yet to lose sight of the shore" (Barros 1778). ${ }^{12}$

Much of the unfounded belief that the Portuguese were leaders in early ocean navigation has been derived from myths and inaccurate history related to the exploits of "Prince Henry the Navigator." The popular consensus pictures the Portuguese Infante Prince Henry assembling Moorish, Genoese, and Spanish (Jewish) scholars at Sagres in the fifteenth century to instruct the Portuguese pilots in advanced navigation and as a result the Portuguese pilots were considered leaders in ocean navigation to include the new, untried, and improperly labelled "celestial navigation." Eva G. R. Taylor agrees with the concept that Columbus learned his navigation from the Portuguese and with unfounded conjecture rather than valid historical evidence asserted he used a Portuguese navigation manual entitled Regimento do Astrolabio e do Quadrante in his 1492 voyage to the New World (Taylor 1953). ${ }^{13}$ Academic Columbian scholars do not seem to understand that a few random "celestial observations" does not constitute "celestial navigation" and Columbus and other early pilots "navigated" solely by dead-reckoning (Peck 2002, 46-59). ${ }^{14}$ There is no valid evidence that Prince Henry's school ever existed. Prince Henry, in spite of his popular title as Navigator, was not interested in navigation and the learned astronomers he assembled did not instruct the Portuguese pilots in navigation, but instead went along on the voyages down the coast of Africa to record the latitude of each new trading port for insertion into the Padrao to establish his ownership of the port and the sovereignty of Portugal. With the preponderance of reliable and documented evidence showing that the Portuguese learned their navigation from the Genoese, it is difficult to understand why prominent Columbian scholars still assert that the well-trained and experienced Genoese navigator Columbus learned his navigation while in Portugal and from Portuguese pilots.

4. COLUMBUS THE GENOESE CAPTAIN. Ferdinand Colón in his Historia quoted from Columbus' 1501 letter to the Spanish sovereigns that began: "From a very young age I began to follow the sea and have continued to do so to this day" (Keen 1992:10). This statement was not contested by the Spanish court or any of Columbus' contemporaries who were well acquainted with his seafaring experience as a Genoese captain and navigator. Yet Davidson from less than astute analysis of irrelevant court records in Genoa voices the current consensus of prominent Columbian scholars that these court records constitute evidence that Columbus was a wool and wine merchant residing in Genoa "many years after he had supposedly gone to sea" (Davidson 1997, 20, emphasis added). This naïve suggestion that when Columbus used the phrase "follow the sea" implied that Columbus should have been constantly at sea with never a brief stint ashore to testify in court litigation regarding the manifested cargo aboard the merchant vessel of which he was the captain hardly deserves a comment. An important and misunderstood evidential factor regarding the identity of Columbus as a wool or wine merchant is the fifteenth-century political structure related to the Monarchal court system in Europe that would manifestly prohibit an unlettered wool or wine merchant from obtaining an audience with the king of Portugal or Spain, but a recognized and respected Genoese captain and pilot would have easily made it through that firewall of protection. 
The Genoese court record known as the "Assereto document" is one of the most important of these court records because it contains collateral information concerning Columbus' age and date of birth. The best translation and commentary on this document (and others) concerning litigation related to a ship's cargo is in the FarinaTolf book which reads in part: "From his [Columbus] declaration under oath, we learn that he was captain of a Genoese ship sailing from Lisbon [not a wool or wine merchant residing in Genoa], a Genoese citizen and approximately 27 years old and that he returned to Lisbon after testifying about the cargo of his ship. The statement regarding his age when analyzed with document 71 [in the book] enables us to put his birth-date between 26 August and 30 October 1451" (Farina-Tolf 1992:47, emphasis added). ${ }^{15}$

It should come as no surprise that the mundane voyages of Columbus prior to 1492 did not receive the attention that was accorded his voyages after he became an important figure of history. Most of the history of Columbus' seafaring accomplishments prior to 1492 has been attained from his own recollections as reported in his letters, postils, and comments in the Diario of his 1492-1493 voyage. And therein lays the problem and underlying reason for the controversy over whether Columbus was a skilled Genoese captain and pilot, or a wool and wine merchant who picked up a limited knowledge of seafaring and navigation while sailing on Portuguese ships.

Columbus' recollections of his earlier voyages were made long after the events and were casual and general in scope and content, so it is quite understandable that they contained minor errors in some of the details. But without valid reason there are prominent historians that point to these errors as indicating the reports are fabrications. It is significant that historians of the twentieth century, far removed from the events in time and space are primarily those who dispute Columbus' reports of his extensive seafaring experience; while contemporary historians (who had ample means to verify or dispute the reports) never doubted that Columbus was a skilled Genoese captain and pilot with long experience at sea.

5. VOYAGES BEFORE 1492. It is beyond the scope of this study to present a detailed analysis of every one of the extant source documents related to Columbus' training, duties, and conduct of voyages prior to 1492 . The brief summary of the voyages and the accompanying chart (Figure 1) are the result of a searching analytical and analogical analysis of all available primary source documents limited to the track and destination of actual voyages. And it should be emphasized that these are only the few voyages for which there is documented evidence and there would have been many other routine voyages for which there is no record.

5.1. 1465-1467. In accordance with Genoese tradition Columbus entered the Genoese maritime trade at about age 14 as an apprentice seaman. These early voyages as a young apprentice are unreported and were ostensibly limited to short voyages along the coast of Italy and to the nearby islands of Corsica, Sardinia, and Sicily. Between voyages Columbus would have continued to be involved in his father's weaving and wine distributor business and attended the weaver's guild school.

5.2. 1457-1474. Understandably, Columbus' voyages during this period are obscure, but were apparently limited to the active Genoese trade routes in the Mediterranean. In Columbus' few extant letters that have survived he refers to voyages in which he visited the ports of the Kingdom of Naples (which would include 


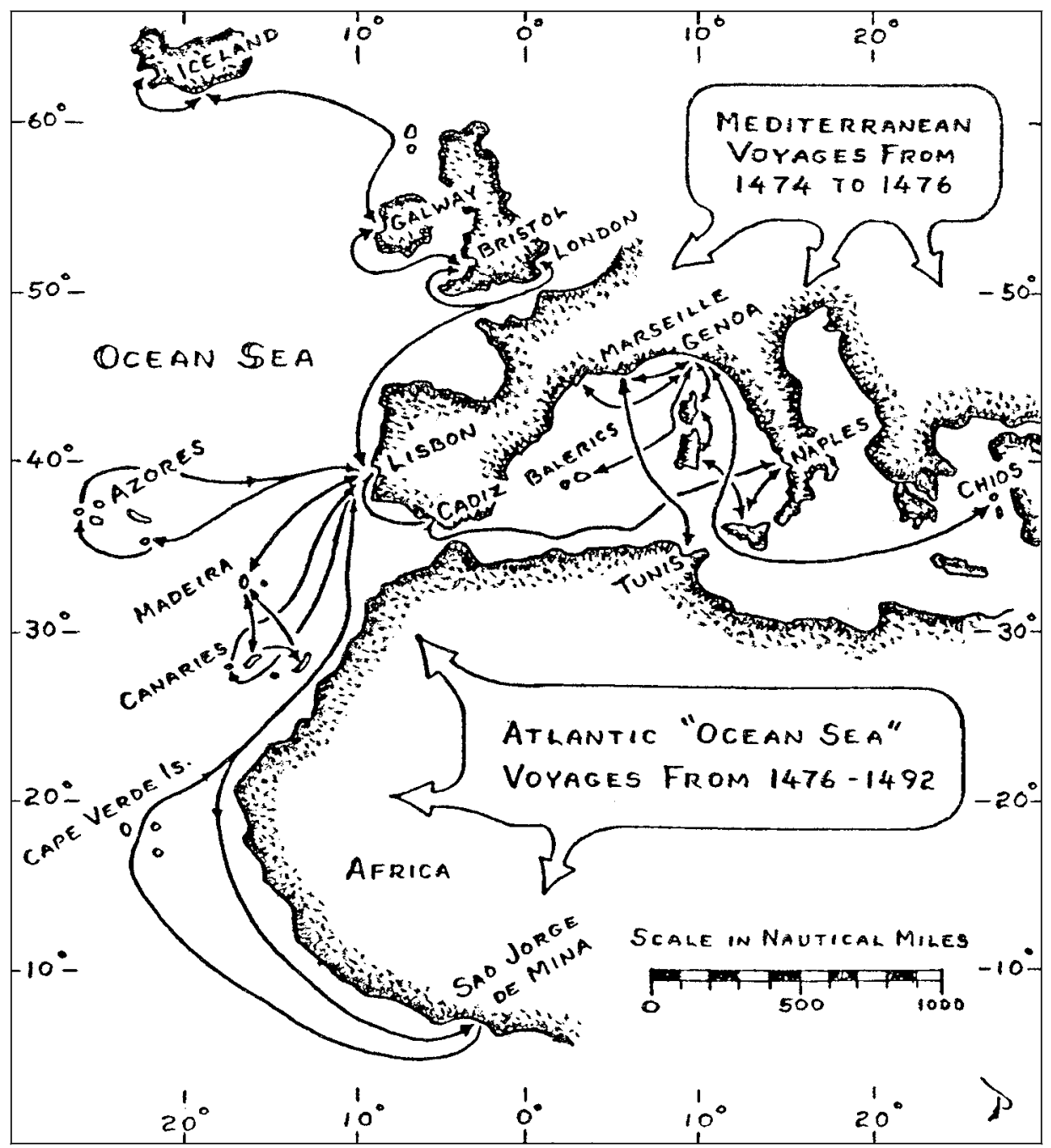

Figure 1. The recorded Mediterranean and Atlantic voyages of Columbus prior to his 1492 voyage.

the satellite ports of Sardinia, Sicily, and Malta), Marseilles, and Hyéres, as well as geographical landfalls at Cape Creus in Catalonia, the Bay of Narbonne, the coast of Sardinia, and the Barbary Coast (Taviani 1985, 52-53).

5.3. 1474-1475. One or possibly more voyages to the island of Chios, a Genoese possession in the far eastern Mediterranean. These voyages were conducted by the Spinola brothers and Paolo Di Negro, prominent Genoese merchants and shipowners whose mercantile enterprises spanned the entire Mediterranean and extended into the Atlantic ports. Columbus would have been an experienced seaman and pilot by this time and ample evidence indicates he formed a lasting working relationship with the Spinola brothers and Paolo Di Negro as captain of one of their fleet of merchant ships operating out of Genoa and the Genoese colony in Lisbon. This 
strong working relationship was confirmed when Columbus remembered both families in his will (Taviani 1985, 47).

5.4. 1475 or 1476. In the service of René d'Anjou as captain and pilot, Columbus carried out a corsair enterprise in Tunisian waters to capture (or recapture?) the Aragonese ship Fernandina. Columbus' action in this instance as a "corsair" is not similar to a pirate as commonly believed, but is more synonymous with the term " privateer," a legitimately authorized action sanctioned by a governmental or other ruling agency to capture what is considered a legitimate prize of war. In Columbus' assigned mission, the Fernandina was probably a French or Spanish vessel from Aragon (on the border between Spain and France) that had earlier been captured by Tunisian pirates. The report of Columbus' corsair mission by his son Ferdinand contains a patently apocryphal and unlikely story about how Columbus reversed the compass needles to fool the crew; a transparent fictional addition with which Ferdinand may have intended to prove some obscure point, but only provided critics of Columbus a strained reason to declare the entire account a fabrication. Ignoring the "reversed needles" fable, the basic account of the voyage would not lend itself to fabrication since such prominent people were involved and thus the event would have been common knowledge. However, Morison, Davidson and others support the fabrication conjecture by insisting that Columbus was too young and inexperienced to have been appointed as captain of the voyage. Columbus was 24 or 25 years of age at this time (see the earlier discussion of "Assereto Document") with ample experience to qualify him as captain of the vessel. Morison was commissioned in 1942 to write the history of the Navy so he should have been familiar with the fact that John Paul Jones, the father of the American Navy, was only 22 when given his first command. Many Columbian scholars seem to be unaware that a vast difference existed between the fifteenth-century and the twentieth century regarding the accepted age of maturity into leadership positions.

5.5. 13 August 1476. The Genoese ship on which Columbus was captain was part of a convoy that was headed for England when attacked and sunk by a fleet of French corsairs commanded by either Guillaume Casanova or Couon le Vieux. In his account of the event Columbus does not specifically state he was the captain of the vessel which has led many historians to assume he was only a minor crew member or passenger. Columbus was writing to a close friend who would have been aware that he was the captain so it is understandable that Columbus would not mention that redundant fact in the account. Columbus swam ashore near the town of Lagos on the Portuguese coast after which he went to Lisbon ostensibly to take refuge in the established Genoese colony (Peck $2007:(1), 473-474)$.

5.6. December 1476-Spring 1477. Undaunted by his experience on the earlier voyage bound for England; Columbus signed on again to sail in a second Genoese convoy to England. While in England he embarked on a ship (probably English not Genoese) from Bristol to an unnamed destination that would have been Iceland since Bristol traders regularly sailed to Iceland in the period. There have been many useless speculations of why Columbus would (or wouldn't) undertake such a voyage, all of which are irrelevant to the overriding evidence that he did take such a voyage and not why he should do so. The voyage to Iceland has been disputed because of Columbus' vague descriptions of marine geographical features, his error in giving the correct latitude, his error in stating it was as large as England, and his statement that the tides rose to 26 fathoms, far above the normal tidal range. Columbus' casual descriptions 
in this instance can be easily explained by the time and context in which the information was given. Here again he was recalling this data many years after the event, but more importantly, the description in his memoir was just a part of a larger discussion aimed at demonstrating that the five terrestrial zones were capable of habitation, rather than solely giving data about this one voyage. Columbus' description of the sea, weather, geography, and atmospheric conditions, although not in the precision required for a nautical almanac, fit the area rather well. Since he saw only a portion of the shoreline he can be forgiven for his estimate that the island was as large as England and he can also be forgiven for his error in reporting the latitude (his source for the figure is uncertain) since no one at the time knew the true latitudes of these northerly islands. And his statement that the tidal range was 26 fathoms can be understood when we consider that Columbus could have easily assumed the tides of Iceland were the same as those of Bristol when writing his memoirs many years after the event. The high tide at Bristol is 14.60 metres (from 1973 British nautical almanac) and when divided by the Genoese measure for a fathom (0.578) the result is 25.26 fathoms (Taviani 1985:320), close enough to Columbus' 26 fathoms in his memoirs.

5.7. 1477-1480. Following the voyage to England Columbus returned to Lisbon, taking up residence in the large Genoese colony where he was associated as a ship's captain and agent for the prominent merchant and ship-owner Paolo Di Negro. Columbus was commissioned by Paolo Di Negro to captain one of his ships from Lisbon to Madeira to buy a large shipment of sugar from a Portuguese trading ship. Columbus was unable to buy the entire load of sugar because he had been given insufficient funds so he engaged in some unclear trading with other Genoese merchants to fill the empty space on his ship. And it was this unorthodox action in this poorly organized trading voyage that resulted in Columbus' appearance as a witness in a Genoese court related to litigation concerning the manifested cargo. The Genoese court record concerning this voyage also indicated that Columbus had been living in the Genoese colony in Lisbon for more than a year, that he was about to return to Lisbon, that he was captain of the vessel and acted for Genoese merchants in Lisbon ("acted for," but not a merchant himself), made the subject trip to Madeira, and finally that this was his most recent trip to Genoa (Farina-Tolf 1992:47). Historians, who are unaware that Columbus served for many years as one of Paolo Di Negro's captains as well as business agent, take the unfounded and irrational view that this and other similar court records related to a ship's cargo indicate that Columbus during this period was in the sugar, wine, or wool business in Genoa (Davidson 1997:19-21) rather than primarily an experienced and sought-after Genoese ship's captain and pilot.

5.8. 1480-1482. At an unclear earlier time Columbus had married Dona Filipa de Perestrello e Moniz, the daughter of Bartolomeo Perestello, the first governor of Porto Santo. During this period Columbus apparently moved from Lisbon and lived on both Porto Santo and Madeira. Las Casas reported: "Columbus went to Porto Santo through contingency, from his desire to navigate and in order to leave his wife there, and because on that island and on the island of Madeira nearby, a great number of ships arrived and there were frequent news of the discoveries that were being made" (Las Casas 1521, 54). While on Porto Santo Columbus' "desire to navigate" apparently led him on numerous voyages to the Canaries and the Azores. There are no records of these voyages and they are inferred from Columbus' knowledge of the geography of the islands expressed in his letters and postils. 
5.9. 1482-1485. Columbus moved back to Lisbon and resumed his prior association with the ship-owner merchants of the Genoese colony as an active captain of an assigned ship from their merchant fleet. During this period he was engaged in the burgeoning trade with the new Portuguese trading ports being established (primarily by Prince Henry the Navigator) along the coast of Africa. Understandably, there are no records of these numerous mundane mercantile voyages, but Columbus had noted them in his letters: "Frequently navigating from Lisbon to Guinea, I observed the route with care (meaning he kept an accurate log giving compass courses and distances) as is usual among naucleres [captains and pilots]" (D'Ailly 1992, emphasis added). ${ }^{16}$ This letter makes it clear that Columbus' sailing on Portuguese ships was as the Genoese captain and pilot rather than just an unskilled seaman as most current Columbus historians report. In between these voyages as a skilled Genoese captain and pilot while sailing under the Portuguese flag and beginning in 1483 or 1484 Columbus presented his plan to sail west to the Indies to King John II and the sceptical Portuguese court. Finally realizing that King John was not going to approve his plan Columbus departed for Spain early in 1485 and entered into a six year period ashore and did not resume active seafaring and navigation until 3 August 1492 when he departed from Palos on his epic voyage to the New World.

6. CONCLUSION. This study has presented viable evidence from reliable sources that Columbus was one of the most skilled and experienced of the respected Genoese captains and navigators in Europe during his lifetime. The consensus of leading academic Columbus scholars that documented evidence picture Columbus as an unlettered wool and wine merchant from Genoa who learned his limited knowledge of seafaring from serving as a minor crew member or passenger on Portuguese voyages reveals a serious lack of realistic, factual, and working knowledge of fifteenth and sixteenth century Maritime history.

\section{REFERENCES}

${ }^{1}$ De Lollis, Cezare (1892), Scritti di Cristoforo Colombo, in Nuova Raccolta Colombiana, Ministry of Cultural and Environmental Assets. With notes comparing Las Casas' Historia de las Indias, Ferdinand's Historie, and Herrera's Historia General, Instuzione del Maggiorasco, Rome.

2 Jane, Cecil (1988), The Four Voyages of Columbus. Originally published as; Select Documents Illustrating the Four Voyages of Columbus; Including those Contained in R. H. Major's "Select Letters of Christopher Columbus," translation with Introduction, notes, and commentary by Cecil Jane. Published by the Hakluyt Society as Vol. 1 (1930) and Vol. 2 (1933). Both volumes combined and published in an unabridged edition by Dover Publications, Inc., New York.

${ }^{3}$ Taviani, Paolo Emilio (1985), Christopher Columbus: The Grand Design. Translated by Luciana F. Farina, Orbis Publishing Limited, London. And Taviani, Paolo Emilio and Consuela Varela (1988), The Journal: Account of the First Voyage and Discovery of the Indies. English edition in two Parts (491 pages); Part I contains a literal translation of the Journal adjacent to the Spanish text with Introduction and ample notes on unclear portions where interpretations are controversial. Part II contains extract translations and commentary on the many Spanish documents and books related to Columbus' voyage. Published in the Nuova Raccolta Colombiana series, Ministry of Cultural and Environmental Assets, Rome.

${ }^{4}$ Varela, Consuela, ed. (1985), “Diario del Primer y Tercer Viaje de Cristóbal Colón,” in Obras de Fray Bartolomé de Las Casas, Alianza Universidad, Madrid.

${ }^{5}$ Davidson, Miles H. (1997), Columbus Then and Now, University of Arizona Press, Tucson. 
${ }^{6}$ Morison, Samuel Eliot (1942), Admiral of the Ocean Sea. Little Brown and Company, New York; and (1974), The European Discovery of America: The Southern Voyages. Oxford University Press, Oxford and New York, pp. 3-161.

${ }^{7}$ Henige, David (1991), In Search of Columbus: The Sources for the First Voyage. University of Arizona Press, Tucson.

8 Wilford, John N. (1991), The Mysterious History of Columbus: An Explanation of the Man, the Myth, the Legacy. Alfred A. Knopf, New York.

${ }^{9}$ Keen, Benjamin (1992), The Life of the Admiral Christopher Columbus by His Son Ferdinand, Rutgers University Press, New Brunswick.

${ }^{10}$ Las Casas, Bartolomé de (1951), Historia de las Indias. Translated into modern Spanish and published in 3 volumes by Fondo de Cultura Económica, Biblioteca Americano, Mexico City.

11 Peck, Douglas T. (2007), "Lisbon," in The Oxford Companion to World Exploration (2 vols.), Oxford University Press, Oxford and New York.

12 Barros, Joao de (1778), Da Asia. Archivo Naciónal, Lisbon.

13 Taylor, Eva G. R. (1953), "The Navigating Manual of Columbus," in Bollettino del Civico Istituto Colombiano, \#1, Genoa.

14 Peck, Douglas T. (2002), "Theory Versus Practical Application in the History of Early Ocean Navigation,” Terrae Incognitae, Vol. 34, pp. 46-59

15 Farina, Luciana F. and Robert W. Tolf (1992), Columbus Documents: Summaries of Documents in Genoa. Translation and commentary on 179 documents from the archives of the State of Genoa including an appendix on Columbus' Book of Privileges, Omnigraphics, Inc., Detroit.

16 D'Ailly, Pierre, (1992), Ymago Mundi y otros opúsculos. Translated by Antonio Ramirez de Verer, Alianza Editorial, Seville. 